\title{
DNA Fingerprinting and Genetic Diversity in Aus Rice (Oryza sativa L.) Landraces of Bangladesh
}

\author{
M A Siddique $^{1^{*}}$, M Khalequzzaman ${ }^{2}$, K Fatema $^{3}$, M Z Islam ${ }^{4}$, M H K Baktiar ${ }^{4}$ and M M Islam $^{5}$
}

\begin{abstract}
The allelic diversity and relationships among 48 Aus rice landraces were determined through DNA fingerprinting using microsatellite (SSR) markers. A total of 14 SSR markers for different chromosomes were used to characterize and differentiate the studied rice genotypes. The number of alleles per locus varied from three alleles (RM118) to 18 alleles (RM44) with an average of 9.88. The polymorphic information content (PIC) varied widely among the loci and ranged from 0.3725 (RM107) to 0.9146 (RM519) with an average of 0.7248 . The genetic distance-based results found in the UPGMA clustering system revealed six genetic groups with a similarity coefficient of 0.35 . Chakila and Shitki saitta had closest distance in the SSR based genetic distance might have same genetic background. Based on genetic coefficient, the diverse landraces Kasalot, Balam, Pankhiraj, Dular, Hashikalmi, Galong, Panbira, Marichbati, Pidi and Surjomoni could be selected as potential parents for varietal improvement programme. The findings of this study should be useful for varietal identification and could be useful for plant breeders in selecting suitable genetically diverse parents for the crossing programme.
\end{abstract}

Key words: Aus rice, DNA fingerprinting, genetic diversity, SSR markers, UPGMA clustering

\section{INTRODUCTION}

Rice (Oryza sativa L.) is one of the most important food crops and a primary source of food for more than half of the world's population (Khush, 2005). It has been cultivated in Asia since ancient times and for generations farmers have maintained thousands of different landraces (Jackson, 1995). Bangladesh is already under pressure both from huge and increasing demands for food, and from problems of agricultural land and water resources depletion. Bangladesh needs to increase the rice yield in order to meet the growing demand for food emanating from population growth. More than $1,27,000$ rice accessions and wild relatives can be found in the world's largest Genebank for rice at IRRI (International Rice Research Institute) based in the Philippines (http://irri.org/ourwork/research/genetic-diversity). Until now, Bangladesh Rice Research Institute (BRRI) has collected and preserved more than 8,000 varieties/landraces/cultivars/wild types from indigenous and exotic sources in the genebank. Out of them, 8,200 have been registered.
For the assessment of plant genetic diversity, the number of scoreable morphological characters is varying as compared to the biological active genes. Moreover, in most cases, plant genomes have large amount of repetitive DNA, which are not expressed and do not contribute to the physiological or morphological appearance of plants. In case of very closely related plant varieties, there are very few morphological differences, which as a matter of fact do not represent the true genetic differences at DNA level. So, there is always a need to study polymorphism at DNA level, which could be an indicator of genetic diversity. Several types of molecular markers viz RFLP, RAPD, AFLP, microsatellites (SSR) and SNP have been developed. PCR-based markers such as simple sequence repeat (SSR) are co-dominant, hyper variable, abundant and well distributed throughout the rice genome (Temnykh et al., 2001). Microsatellites have shown great promise in genetic diversity, genome mapping, gene tagging and markerassisted selection (MAS) because they are technically simple, time saving, highly

\footnotetext{
${ }^{1} \mathrm{SSO} .{ }^{2} \mathrm{CSO}$ and Head. ${ }^{3} \mathrm{SO}$, NATP (Phase I)-SPGR project. ${ }^{4} \mathrm{SO}$, Genetic Resources and Seed Division, BRRI, Gazipur; and ${ }^{5} \mathrm{SSO}$, Biotechnology Division, BINA, Mymensingh. *Corresponding author's E-mail: mabs198401@yahoo.com
} 
informative and require small amount of DNA. Microsatellite markers are now available through the published high-density linkage map (McCouch et al., 2002; IRGSP, 2005) or public database. A study was conducted on 234 rice landraces in Plant breeding division, Cornell University and they identified five distinct groups corresponding to indica, aus, aromatic, temperate japonica and tropical japonica rice (Amanda et al., 2004). They also have very high diversity with $98 \%$ of loci polymorphic Aus group. Despite their drought tolerance and early maturity, the group has received less attention compared to indica and japonica group.

There are four distinct ecotypes of riceBoro, Aus, Transplanted Aman and Deep water Aman in Bangladesh. Bangladesh has a good source of indigenous rice cultivars comprising Boro, Aman and Aus landraces. Those landraces have good adaptation having poor yield. Actually cultivation of these landraces was gradually replaced by high yielding varieties during the last 20 years. These landraces adapted in different parts of the country, some of which have very nice quality, fineness, aroma, taste and high protein contents (Dutta et al., 1998). After establishment of BRRI, DNA fingerprinting has been done only of a small number of local landraces. Indigenous rice landraces were characterized at both molecular and phenotypic level by many countries. They have been done for their crop identity and searched for new genes for further crop improvement. However, information on the genetic diversity of local landraces particularly for Aus rice is very scanty in Bangladesh. Precise information on the extent of genetic diversity among population is crucial in any crop improvement programme, as selection of plants based on genetic diversity has become successful in several crops (Ananda and Rawat, 1984; De et al., 1988). Hence, the objectives of this research were to (1) assess the genetic variation and diversity of 48 Aus rice genotypes, (2) determine the genetic relationship among these genotypes for breeding purposes, and (3) characterize these rice genotypes at molecular level (DNA fingerprinting) that would help in the establishment of varietal rights.

\section{MATERIALS AND METHODS}

\section{Plant materials}

Forty-eight Aus rice landraces were used in this study (Table 1). A five gram seed from each of the entry was germinated and then sown in earthen pots for growth and subsequent DNA extraction.

\section{SSR markers}

Fourteen SSR markers were selected (Table 2) to detect DNA for discriminating the tested Aus rice landraces.

\section{Genotyping protocol}

Total genomic DNA was extracted from young leaves of three-week-old plants following the simple and modified protocol of Zheng et al., 1995. PCR analysis was performed in $12.5 \mu 1$ reaction sample containing 5-25 ng of DNA template, $1.25 \mu \mathrm{l}$ of $\mathrm{MgCl}_{2}$ free 10X PCR buffer (100 mM Tris- $\mathrm{HCl} \mathrm{pH} 9.0$ at $25^{\circ} \mathrm{C}, 500 \mathrm{mM}$ $\mathrm{KCl}, 0.1 \%$ Triton $^{\circledR} \mathrm{X}-100$ and $\left.\mathrm{H}_{2} \mathrm{O}\right), 1.5 \mu \mathrm{l}$ of 25 $\mathrm{mM} \mathrm{MgCl}{ }_{2}, 0.25 \mu \mathrm{l}$ of $10 \mathrm{mM}$ dNTP, $0.25 \mu \mathrm{l}$ of $5 \mathrm{U} / \mu \mathrm{l}$ Taq polymerase enzyme, $0.625 \mu \mathrm{l}$ each of $10 \mu \mathrm{M}$ forward and reverse primers using a MJ Research single 96-well thermal cycler. The mixture was overlaid with one drop of mineral oil to prevent evaporation. After initial denaturation for five minutes at $94^{\circ} \mathrm{C}$, each cycle comprised one min denaturation at $94^{\circ} \mathrm{C}$, one min annealing at $55^{\circ} \mathrm{C}$, and two min extension at $72^{\circ} \mathrm{C}$ with a final extension for sevem min at $72^{\circ} \mathrm{C}$ at the end of 35 cycles. The PCR products were mixed with bromophenol blue gel loading dye and were analyzed by electrophoresis on $8 \%$ polyacrylamide gel using mini vertical polyacrylamide gels for high throughput manual genotyping (CBS Scientific Co. Inc., CA, USA). $2.5 \mu \mathrm{l}$ of amplification products were resolved by running gel in $1 \times \mathrm{TBE}$ buffer for 2-2.5 hrs depending upon the allele size 
Table 1. Rice landraces used in the present study with their provenance.

\begin{tabular}{|c|c|c|c|c|c|}
\hline Landrace & BRRI accession no. & Place of collection & Landrace & BRRI accession no. & Place of collection \\
\hline Kasalot & 3283 & Sylhet & Panbira & 50 & Dhaka \\
\hline Balam & 4945 & Khulna & Hasha kumira & 63 & Manikganj \\
\hline Kamranga & 4926 & Rangamati & Dhala saita & 64 & Manikganj \\
\hline Surjomoni & 3550 & Barisal & Loroi & 65 & Dhaka \\
\hline Gopalbogh & 2110 & Narsingdi & Boteswar & 66 & Dhaka \\
\hline Haitta & 3232 & Tangail & Chakila & 152 & Tangail \\
\hline Goarchara & 953 & Khulna & Shitki saita & 154 & Tangail \\
\hline Chengri & 808 & Sylhet & Baila bokri & 155 & Tangail \\
\hline Saita & 1052 & Jessore & Kataktara (2) & 183 & Mymensingh \\
\hline Company & 7270 & Khagrachhari & Bolorum & 188 & Mymensingh \\
\hline Galon & 743 & Chittagong & Pankiraj & 189 & Mymensingh \\
\hline Kamarang & 7263 & Khagrachhari & Hanpa & 190 & Mymensingh \\
\hline Maloti & 7269 & Khagrachhari & Agaua & 191 & Mymensingh \\
\hline Lal binni & 753 & Chittagong & Chakulia & 193 & Mymensingh \\
\hline Suri dhan & 7264 & Khagrachhari & Shala dumra & 263 & Rangpur \\
\hline Galong & 7265 & Khagrachhari & Sukhti & 264 & Rangpur \\
\hline Sada galon & 4923 & Rangamati & Faisha manja & 265 & Rangpur \\
\hline Sili & 7251 & Bandarban & Inda & 266 & Rangpur \\
\hline Mongthong & 7249 & Bandarban & Thubri & 267 & Rangpur \\
\hline Kilong & 7257 & Bandarban & Bolun & 268 & Rangpur \\
\hline Dharial & 18 & Dhaka & Phul dumra & 269 & Rangpur \\
\hline Dular & 22 & Dhaka & Kola dama & 271 & Rangpur \\
\hline Hashikalmi & 30 & Dhaka & Turki & 7423 & Khagrachhari \\
\hline Marichbati & 47 & Dhaka & Pidi & 7770 & Bandarban \\
\hline
\end{tabular}

Table 2. List of the 14 SSR markers.

\begin{tabular}{|c|c|c|c|c|}
\hline $\begin{array}{l}\text { Locus } \\
\text { name }\end{array}$ & $\begin{array}{l}\text { Chr. } \\
\text { no. }\end{array}$ & $\begin{array}{c}\text { Repeat } \\
\text { motif }\end{array}$ & Forward primer & Reverse primer \\
\hline RM6 & 2 & (AG)16 & GTCСССТССАСССААТTC & TCGTCTACTGTTGGCTGCAC \\
\hline RM204 & 6 & (CT) 44 & GTGACTGACTTGGTCATAGGG & GCTAGCCATGCTCTCGTACC \\
\hline RM241 & 4 & (CT)31 & GAGCCAAATAAGATCGCTGA & TGCAAGCAGCAGATTTAGTG \\
\hline RM279 & 2 & (GA)16 & ССТCTCACTCACGTGGACTCTCC & СCTCACCCTAGGCTTTGATATGC \\
\hline RM519 & 12 & (AAG)8 & AGAGAGCCCCTAAATTTCCG & AGGTACGCTCACCTGTGGAC \\
\hline RM286 & 11 & (GA)16 & GGCTTCATCTTTGGCGAC & CCGGATTCACGAGATAAACTC \\
\hline RM44 & 8 & (GA)16 & ACGGGCAATCCGAACAACC & TCGGGAAAACCTACCCTACC \\
\hline RM147 & 10 & (TTCC)5(GGT)5 & TACGGCTTCGGCGGCTGATTCC & CCCCCGAATCCCATCGAAACCC \\
\hline RM107 & 9 & $(\mathrm{GA}) 7$ & AGATCGAAGCATCGCGCCCGAG & ACTGCGTCCTCTGGGTTCCCGG \\
\hline RM118 & 7 & $(\mathrm{GA}) 8$ & CCAATCGGAGCCACCGGAGAGC & CACATCCTCCAGCGACGCCGAG \\
\hline RM10 & 7 & (GA)15 & TTGTCAAGAGGAGGCATCG & CAGAATGGGAAATGGGTCC \\
\hline RM161 & 5 & (AG)20 & TGCAGATGAGAAGCGGCGCCTC & TGTGTCATCAGACGGCGCTCCG \\
\hline RM1 & 1 & $(\mathrm{GA}) 26$ & GCGAAAACACAATGCAAAAA & GCGTTGGTTGGACCTGAC \\
\hline RM85 & 3 & (TGG)5(TCT)12 & CCAAAGATGAAACCTGGATTG & GCACAAGGTGAGCAGTCC \\
\hline
\end{tabular}

Chr.=Chromosome. 
at around 75 volts and $180 \mathrm{~mA}$ current. The gels were stained in $0.5 \mathrm{mg} / \mathrm{ml}$ ethidium bromide and were documented using UVPRO (Uvipro Platinum, EU) gel documentation unit. Microsatellite or simple sequence repeat (SSR) markers were used for DNA analysis (Temnykh et al., 2001; McCouch et al., 2002).

\section{Data analysis}

Size for each amplified allele was measured in base pair using Alpha-EaseFC 5.0 software. The summary statistics including thenumber of alleles per locus, major allele frequency, gene diversity, polymorphism information content (PIC) values were determined using PowerMarker version3.25 (Liu and Muse, 2005). The allele frequency data from Power Marker was used to export in binary format (allele presence $=1$ and allele absence=0) for analysis with NTSYSpc version 2.1 (Rohlf, 2002). A similarity matrix was calculated with the Simqual subprogramme using the Dice coefficient, followed by cluster analysis with the SAHN subprogramme using the UPGMA (unweighted pair group method using arithmetic mean) clustering method as implemented in NTSYS-pc.

\section{RESULTS AND DISCUSSION}

\section{Overall SSR diversity}

Forty-eight Aus landraces were successfully amplified with the 14 SSR marker pairs where marker pairs referred to as loci and DNA bands as alleles. A total of 138 alleles were detected using 14 microsatellite markers across 48 rice landraces. The number of alleles per locus ranged from three alleles (RM118) to 18 alleles (RM44), with an average of 9.88 (Table 3). PIC values ranged from 0.3725 (RM107) to 0.9146 (RM519) with an average of 0.7248 . The PIC values for other markers were 0.9135 (RM286), 0.9115 (RM44), 0.8620 (RM147), 0.8439 (RM6), 0.8247 (RM279), 0.7961 (RM241), 0.7371 (RM85), 0.7252 (RM204), 0.6867 (RM1), 0.6251 (RM10), 0.5301 (RM161) and 0.4038 (RM118) respectively. The allele frequency ranged from 12.50\% (RM519, RM286, RM44) to $77.08 \%$ (RM107) with an average of 35.12 (Table 3 ). PIC value revealed RM519 as the best marker. Figugre 1 shows the DNA profiles of 48 Aus rice landraces with SSR marker RM519.

\section{Genetic distance-based analysis}

The SSR marker data were subjected to cluster analysis using NTSYS programme. The similarity matrix was constructed using Dice coefficient method. Cluster analysis was done to group the genotypes into a dendrogram. From this dendrogram, the 48 rice landraces were grouped into six major clusters at a coefficient of 0.35 and the similarity coefficient value ranged from 0.10 to 0.86 . Cluster I consisted of 18 accessions and is the biggest group among six clusters, followed by cluster IV which contained 11 accessions; cluster V comprised nine accessions; cluster II comprised six accessions; cluster III and VI were both composed of two accessions (Fig. 2 ).

In rice improvement breeding programme the genetically diverse landraces could be chosen as parents for crossing programme to create genetic variability and can be used as transgressive segregants. It was found that two Aus landraces (Chakila and Shitki saita) were sorted out as exactly same genotypes in this analysis might possess same genetic background. Hence, microsatellite marker based molecular fingerprinting could serve as a potential basis in the identification of genetically distant accessions as well as in duplicate sorting of the morphologically close accessions.

In the present investigation, the SSR markers generated 138 alleles with the number of alleles per locus varying from 3 to 18. Similar number of microsatellite markers previously used as subset for genetic diversity analysis of O. sativa (Siddique et al., 2016a). The average number of alleles per locus was 9.88, indicating a greater magnitude of diversity among the rice landraces. This value is comparable to five alleles (RM275) to 15 alleles (RM180), with an average of 9.7 across the 30 loci (Siddique et al., 2016b). The PIC values 
Table 3. Allele number, allele size, allele frequency and PIC of 48 Aus rice landraces for 14 SSR markers.

\begin{tabular}{lcccccc}
\hline Marker & Chr. no. & Position $(\mathrm{cM})$ & Allele no. & Allele size range $(\mathrm{bp})$ & Allele freq $(\%)$ & PIC value \\
\hline RM6 & 2 & 29.57 & 12 & $142-178$ & 27.08 & 0.8439 \\
RM204 & 6 & 24.04 & 8 & $106-118$ & 39.58 & 0.7252 \\
RM241 & 4 & 26.82 & 12 & $101-127$ & 33.33 & 0.7961 \\
RM279 & 2 & 13.2 & 11 & $119-136$ & 27.08 & 0.8247 \\
RM519 & 12 & 19.90 & 16 & $117-145$ & 12.50 & 0.9146 \\
RM286 & 11 & 0.38 & 15 & $95-123$ & 12.50 & 0.9135 \\
RM44 & 8 & 2.88 & 18 & $97-122$ & 12.50 & 0.9115 \\
RM147 & 10 & 20.68 & 14 & $87-109$ & 27.08 & 0.8620 \\
RM107 & 9 & 20.06 & 6 & $165-187$ & 77.08 & 0.3725 \\
RM118 & 7 & 28.01 & 3 & $163-166$ & 52.08 & 0.4038 \\
RM10 & 7 & 6.50 & 4 & $156-148$ & 43.75 & 0.6251 \\
RM161 & 5 & 27.89 & 4 & $163-189$ & 43.75 & 0.5301 \\
RM1 & 1 & 4.63 & 7 & $80-90$ & 41.67 & 0.6867 \\
RM85 & 3 & 66.76 & 8 & $89-117$ & 4167 & 0.7371 \\
Mean & & & 10 & & 35.12 & 0.7248 \\
\hline
\end{tabular}

Motif of the SSR and number of repeats as previously published (http:/ / www.gramene.org).

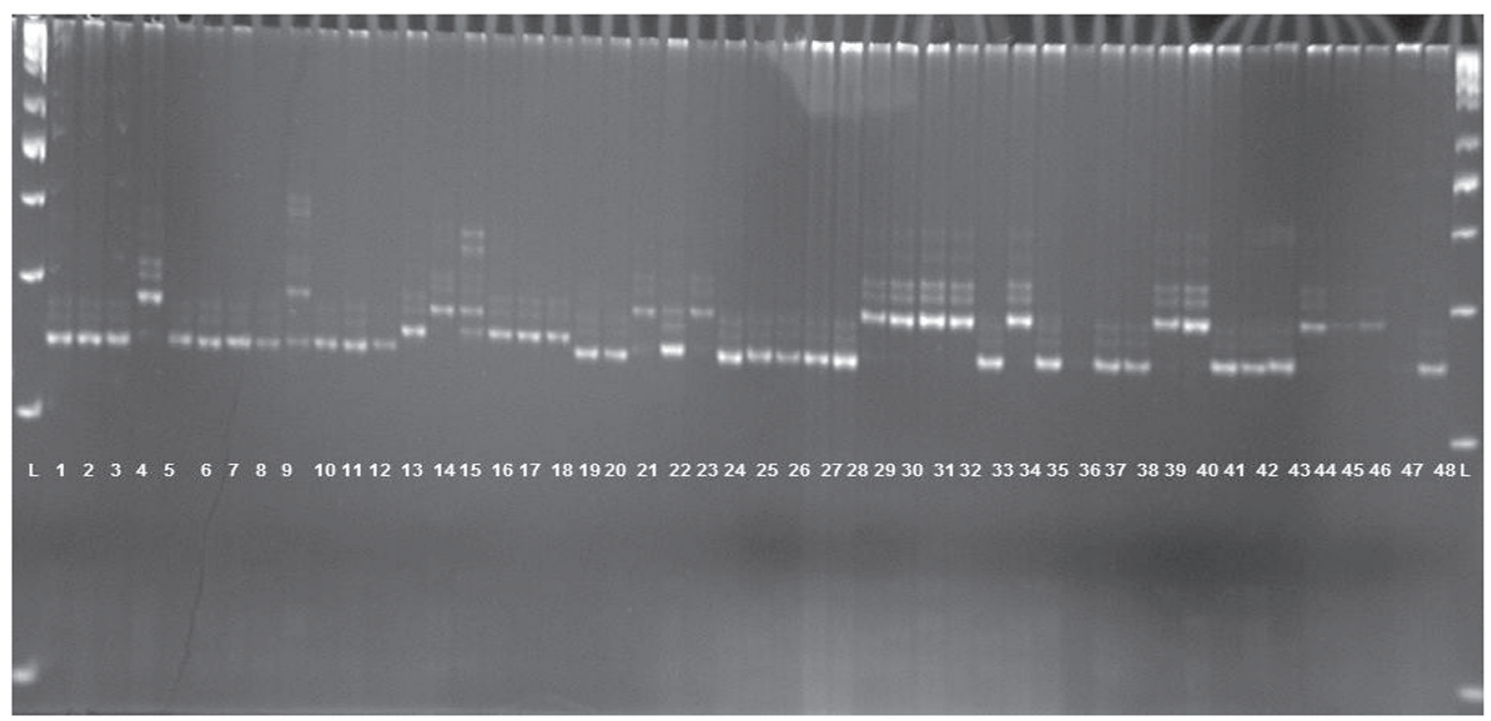

Fig. 1. DNA profile of 48 Aus rice landraces with RM519.

Legend: Lane 1=Kasalat, 2=Balam, 3=Kamranga, 4=Surjomoni, 5=Gopalbogh, $6=$ Haitta, $7=$ Goarchara, $8=$ Chengri, $9=$ Saita, 10=Company, 11=Kamarang, 12=Maloti, 13=Lalbinni, 14=Suridhan, 15=Galong, 16=Sada galon, 17=Sili, 18=Mongthong, 19=Kilong, 20=Dharial, 21=Dular, 22=Hashikalmi, 23=Marichbati, 24=Panbira, 25=Hasha kumira, 26=Dhala saita, 27=Loroi, 28=Boteswar, 29=Chakila, 30=Shitki saita, 31=Baila bokri, 32=Kataktara (2), 33=Bolorum, 34=Pankiraj, 35=Hanpa, 36=Agaua, 37=Chakulia, 38=Shala dumra, 39=Sukhti, 40=Faisha manja, 41=Inda, 42=Thubri, 43=Bohum, 44=Phul durma, 45=Kola dama, 46=Bangal bakri, 47=Turki, 48=Pidi.

ranged from 0.37 (RM107) to 0.91 (RM519, rice viz. 0.34-0.88 (Thomson et al., 2007), 0.65RM286, RM44) with an average of 0.7248. 0.91 (Siddique et al., 2014), 0.59-0.90 (Siddique The PIC values observed, are comparable to et al., 2016b). The alleles revealed by markers previous estimates of microsattelite analysis in showed a high degree of polymorphism. The 


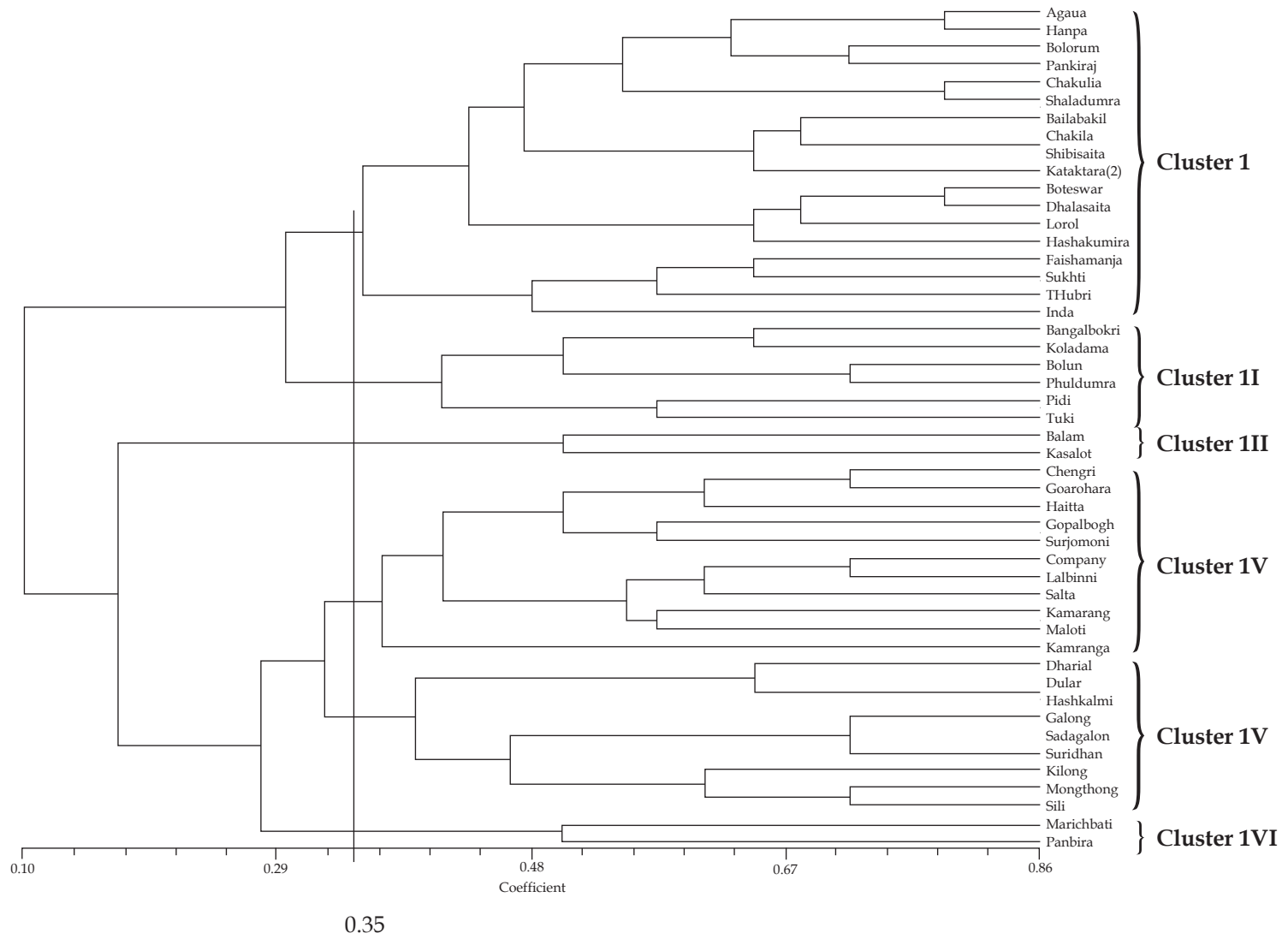

Fig. 2. An UPGMA eluster dendogram showing the genetic relationship among 48 Aus landrances based on the alleles detected by 14 SSR markers.

mean PIC value observed in this study was higher than the PIC value of 0.578 recorded by Ravi et al., (2003) in an earlier study among rice cultivars, landraces and wild relatives. This could indicate that the genotypes used in the present study were more diverse. Panaud et al., (1996) described high genetic similarity among landraces of common geographic origin and low similarity among landraces of diverse geographic origins using SSR markers in rice.

\section{CONCLUSIONS}

The results obtained from this study provided some useful implications for establishment of Intellectual Property Rights (IPR) issues of
Bangladeshi rice landraces. There was a high level of genetic diversity among accessions of Aus rice landraces, suggesting that SSR markers were effective in the detection of polymorphism in this ecosystem. To broaden the genetic base and for the improvement of Aus rice, landraces having the lowest genetic similarities could be selected as parents. Therefore, hybridization should be made between two distant populations. Considering all these criteria and results, the diverse landraces Kasalot, Balam, Pankhiraj, Dular, Hashikalmi, Galong, Panbira, Marichbati, Pidi and Surjomoni could be selected as parents for further breeding programmes. This will bring about greater diversity, which will lead to a high productive index in terms of increase in yield and overall quality. 


\section{ACKNOWLEDGEMENTS}

The authors are grateful to Coordinated subproject on Characterization of important plant genetic resources supported by World Bank through the NATP (Phase-I)-SPGR, Bangladesh Agricultural Research Council for providing funds for this research.

\section{REFERENCES}

Amanda, J G, T H Tai, J Coburn, S Kresovich and S McCouch. 2004. Genetic structure and diversity in Oryza sativa L. Genetics 169: 1631-1638.

Ananda, I J and D S Rawat. 1984. Genetic diversity, combining ability and heterosis in brown mustard. Indian J. Genet. 44: 226-234.

De, R N, R Setharam, M K Sinha and S P Banarjee. 1988. Genetic divergence in rice. Indian J. Genet. 48: 189-194.

Dutta, R K, B P Lahiri and M A Baset Mian. 1998. Characterization of some aromatic and fine rice cultivars in relation to their phsico-chemical quality of grains. Indian J. Plant Physil. 3 (1): 61-64.

IRGSP. 2005. The map-based sequence of the rice genome. Nature 436: 793-800.

Jackson, M T. 1995. Protecting the heritage of rice biodiversity. GeoJournal 35: 267-274.

Khush, G S. 2005. What it will take to feed 5.0 billion rice consumers in 2030. Plant Mol. Biol. 59: 1-6.

Liu, K and S V Muse. 2005. PowerMarker: Integrated analysis environment for genetic marker data. Bioinformatics 21: 2128-2129.

McCouch, S R, L Teytelman, Y Xu, K B Lobos, K Clare, M Walton, B Fu, R Maghirang, Z Li, Y Xing et al., 2002. Development and mapping of 2240 new SSR markers for rice (Oryza sativa L.). DNA Res. 9: 199-207.
Panaud, O, X Chen and S R McCouch. 1996. Development of microsatellites markers and characterization of simple sequence length polymorphism (SSLP) in rice (O. sativa L.). Mol. Gen. Genet. 252: 597-607.

Ravi, M, S Geethanjali, F Sameeyafarheen and M Maheswaran. 2003. Molecular marker based genetic diversity analysis in Rice (Oryza sativa L.) using RAPD and SSR markers. Euphytica 133: 243-252.

Rohlf, F. 2002. NTSYS-pc: Numerical taxonomy and multivariate analysis system, $2.2 \mathrm{edn}$. Department of Ecology and Evolution, State University of NY, Stony Brook.

Siddique, M A, M Khalequzzaman, K Fatema, M Z Islam, M M Islam and M A Z Chowdhury. 2016a. Molecular characterization and genetic diversity of Aman rice (Oryza sativa L.) landraces in Bangladesh. Bangladesh Rice J. 20 (2): 1-11.

Siddique, M A, M Khalequzzaman, M M Islam, K Fatema and M A Latif. 2016b. Molecular characterization and genetic diversity in geographical indication (GI) rice (Oryza sativa L.) cultivars of Bangladesh. Brazilian J. Bot. : 1-10 (DOI 10.1007/s40415-0160271-1).

Siddique, M A, E S M H Rashid, M Khalequzzaman, M K Bashar and L R Khan. 2014. Molecular characterization and genetic diversity in T. Aman landraces of Rice (Oryza sativa L.) using microsatellite markers. Thai J. Ag. Sci. 47 (4): 211-220.

Temnykh, S, G DeClerck, A Lukashova, L Lipovich, S Cartinhour and S R McCouch. 2001. Computational and experimental analysis of microsatellites in rice (Oryza sativa L.), frequency, length variation, transposon associations and genetic marker potential. Genome Res. 11: 1441-1452.

Thomson, M J, E M Septiningsih, F Suwardjo, T J Santoso, T S Silitonga and S R McCouch. 2007. Genetic diversity analysis of traditional and improved Indonesian rice (Oryza sativa L.) germplasm using microsatellite markers. Theoret. and Appl. Genet. 114 (3): 559-568.

Zheng, K, N Huang, J Bennet and G S Khus. 1995. PCRbased marker assisted selection in rice breeding, IRRI, Manila, Philippines, pp. 16-18. 
